\title{
GROWTH OF ASPERGILLUS OCHRACEUS, A. CARBONARIUS AND A. NIGER ON CULTURE MEDIA AT DIFFERENT WATER ACTIVITIES AND TEMPERATURES
}

\author{
Héctor Palacios-Cabrera ${ }^{1}$; Marta Hiromi Taniwaki ${ }^{1 *}$; Jorge Minoru Hashimoto ${ }^{1}$; Hilary Castle de Menezes ${ }^{2}$ \\ ${ }^{1}$ Instituto de Tecnologia de Alimentos, Campinas, SP, Brasil; ${ }^{2}$ Faculdade de Engenharia de Alimentos, Universidade Estadual de \\ Campinas, Campinas, SP, Brasil
}

Submitted: March 10, 2004; Approved: February 01, 2005

\begin{abstract}
The objective of this paper was to determine the influence of three culture media with different water activities, times of incubation and temperatures on the growth of A. ochraceus, A. carbonarius and A. niger. Spores of A. ochraceus, A. carbonarius and A. niger were inoculated onto three culture media: Czapeck Yeast extract Agar (CYA), Dichloran 18\% Glycerol Agar (DG18) and Malt Yeast extract 40\% Glucose Agar (MY40G). The plates were incubated at five different temperatures $\left(8,25,30,35\right.$ and $\left.41^{\circ} \mathrm{C}\right)$. The growth of fungi was evaluated every $24 \mathrm{~h}$, measuring the colony diameter $(\mathrm{mm})$. None of the species grew at $8^{\circ} \mathrm{C}$ in any culture media. For $A$. carbonarius, $30^{\circ} \mathrm{C}$ was the best temperature for growth while for $A$. niger temperatures above $30^{\circ} \mathrm{C}$ were better in all culture media. A. ochraceus presented good growth at 25 and $30^{\circ} \mathrm{C}$ in all culture media, while at $35^{\circ} \mathrm{C}$, growth was slower, especially on CYA. At $41^{\circ} \mathrm{C}, A$. ochraceus did not grow in any culture media and A. carbonarius was significantly inhibited. A. niger grew at $41^{\circ} \mathrm{C}$ and was shown to be the most xerophilic fungi when compared to A. carbonarius and A. ochraceus.
\end{abstract}

Key words: Aspergillus ochraceus, Aspergillus carbonarius, Aspergillus niger, growth measurement, water activity, temperature

\section{INTRODUCTION}

Fungi are significant environmental microrganisms especially in foods where they are responsible for spoilage, production of mycotoxins and, in some cases desirable bioconversions. Consequently, it is important to know their requirements for water, temperature, nutrients, oxygen and other factors for their growth. The most common genera of fungi in food are Aspergillus, Penicillium and Fusarium. Several species of these genera are able to produce mycotoxins, which are of concern to public health. Among them, ochratoxin A is nefrotoxic and carcinogenic to some animals $(20,25)$ and has been detected in different types of foods such as cocoa and cocoa products (14), coffee $(11,22,23)$, dried fruits $(12,13)$, cereals (9), wines $(15,26,27)$, beer $(5)$ and others (2). Ochratoxin A (OA) is believed to be produced in nature by three main species of fungi, Aspergillus ochraceus, A. carbonarius and Penicillium verrucosum, with a minor contribution by $A$. niger (8). P. verrucosum is believed to occur only in cool temperate climates, and is mainly associated with cereals $(18,19)$. A. carbonarius and $A$. niger were described as sources of OA $(1,6,24)$. A. ochraceus has been isolated from several green coffee samples originating from coffee producing countries $(4,23)$.

Several data of growth conditions for A. niger and A. ochraceus have been recorded. However, little has been published about A. carbonarius. Most information about its physiology is assumption based on A. niger, because of its similarity. It may be closely related, but it differs from A. niger most notably in the production of larger spores (10). The importance of studying A. carbonarius is because of its ability to produce ochratoxin $\mathrm{A}$, which is much greater than that of $A$. niger. A. niger has been reported to grow optimally at relatively high temperatures, with a maximum of 45 to $47^{\circ} \mathrm{C}$ and optimal conditions from 35 to $37^{\circ} \mathrm{C}$. This species has been reported as a

*Corresponding Author. Mailing address: Instituto de Tecnologia de Alimentos, Av. Brasil, 2880. 13073-001, Campinas, SP, Brasil. Tel.: (+5519)

3743-1820, Fax: (+5519) 3743-1822. E-mail: mtaniwaki@ital.sp.gov.br 
xerophile with germination reported at $0.77 \mathrm{a}_{\mathrm{w}}$ at $35^{\circ} \mathrm{C}(19) . A$. ochraceus has been described as a mesophilic xerophile. Growth occurs between 8 and $37^{\circ} \mathrm{C}$, with the optimum from 24 to $31^{\circ} \mathrm{C}$ $(16,19,21)$. Previous studies suggest that the $\mathrm{a}_{\mathrm{w}}$ minima for $A$. ochraceus varies from 0.76 to 0.88 depending on the substrate (3) and the optimum from 0.98 to 0.96 (21). The objective of this work was to study the effect of temperature, culture media and water activity $\left(\mathrm{a}_{\mathrm{w}}\right)$ on the growth of three OA producing fungi: A. niger, A. carbonarius and A. ochraceus.

\section{MATERIALS AND METHODS}

\section{Fungal species}

Three species of fungi producers of ochratoxin A isolated from green coffee from São Paulo State, Brazil by Taniwaki et al. (23) were studied: A. niger ITAL 704, A.carbonarius ITAL 170 and $A$. ochraceus ITAL 118.

\section{Culture media}

The following media were used: Czapeck Yeast Extract Agar (CYA), $\mathrm{a}_{\mathrm{w}} 0.997$ (17); Dichloran 18\% Glycerol Agar (DG18), $\mathrm{a}_{\mathrm{w}} 0.955$ (7) and Malt Yeast 40\% Glucose Agar (MY40G), $\mathrm{a}_{\mathrm{w}} 0.897$ (19).

\section{Cultivation}

Cultures were grown on each medium in standard size $(85 \mathrm{~mm})$ plastic Petri dishes. Inocula were prepared from 5 day old cultures grown on Malt Extract Agar (MEA) (17). A suspension of spores was prepared in a phosphate buffer $(\mathrm{pH}$ 7.2) with $0.1 \%$ of Tween 80 . The spores were counted in a haemacytometer giving $10^{4}$ spores $/ \mathrm{ml}$. A drop of suspension of each fungus was inoculated, separately, on the centre of each culture medium. Plates were incubated upright at temperatures of: 8, 25, 30, 35 and $41^{\circ} \mathrm{C}$. All experiments were performed in 6 replicates.

\section{Growth Measurements}

Fungal growth was measured at intervals of $24 \mathrm{~h}$ after the third day of incubation. The reverse side of the colonies was measured in millimetres with a ruler.

\section{Statistical analysis}

Co-variance was used to analyse colony diameter so that the effects of one or more factors $\left(a_{w}\right.$, temperature, species and time) could be assessed separately, for statistically significant differences. The SAS System (version 6.12, SAS Institute, Cary, NC 27513, USA) statistical package was used.

\section{RESULTS}

The growth of A. ochraceus, A. carbonarius and A. niger on different culture media, time and temperatures is shown in Figs. 1 to 3 , respectively.

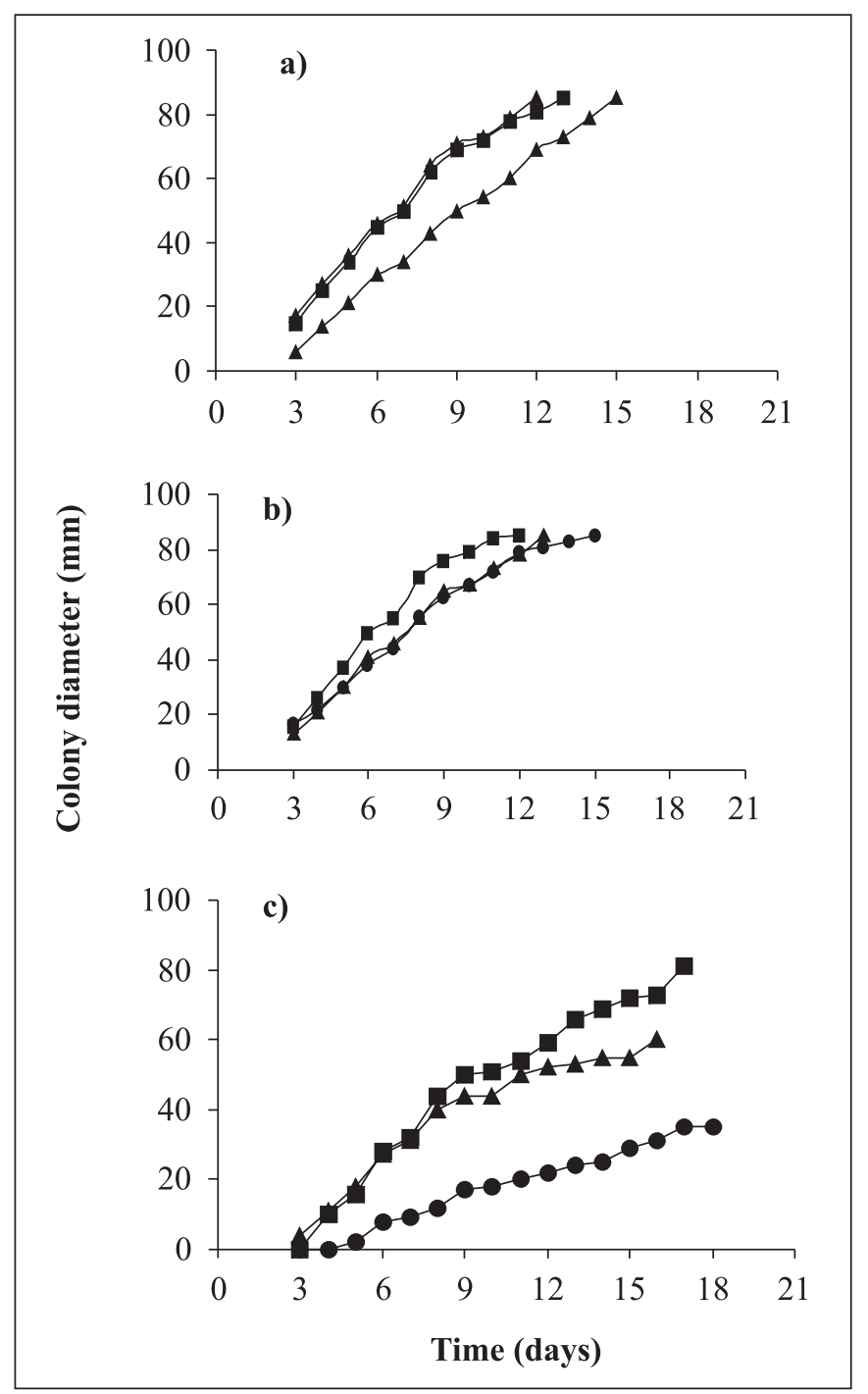

Figure 1. Growth of A. ochraceus on three different culture media ( CYA; DG18; $\triangle$ MY40G) at the temperatures of a) $25^{\circ} \mathrm{C}$; b) $30^{\circ} \mathrm{C}$; c) $35^{\circ} \mathrm{C}$.

The results represent an average of 6 replicates. At $8^{\circ} \mathrm{C}$ there was no growth of any of these three species on the three culture media. As shown in Fig. 1, the temperatures of 25 and $30^{\circ} \mathrm{C}$ favoured fast colony diameter growth for A. ochraceus. On the other hand, slower growth can be observed at $35^{\circ} \mathrm{C}$ and total inhibition at $41^{\circ} \mathrm{C}$ on all of the culture media. At $35^{\circ} \mathrm{C}, A$. ochraceus grew better on DG18 and MY40G than on CYA. A more xerophilic character may be attributed to this fungus at $35^{\circ} \mathrm{C}$. For $A$. carbonarius, $30^{\circ} \mathrm{C}$ was shown to be the best temperature for its growth on CYA, DG18 and MY40G. A. carbonarius grew poorly at $41^{\circ} \mathrm{C}$ reaching 12,33 and $40 \mathrm{~mm}$ on CYA, DG18 and MY40G, respectively, and with no more growth after 6 to 8 days (Fig. 2). In general, growth of $A$. niger was 


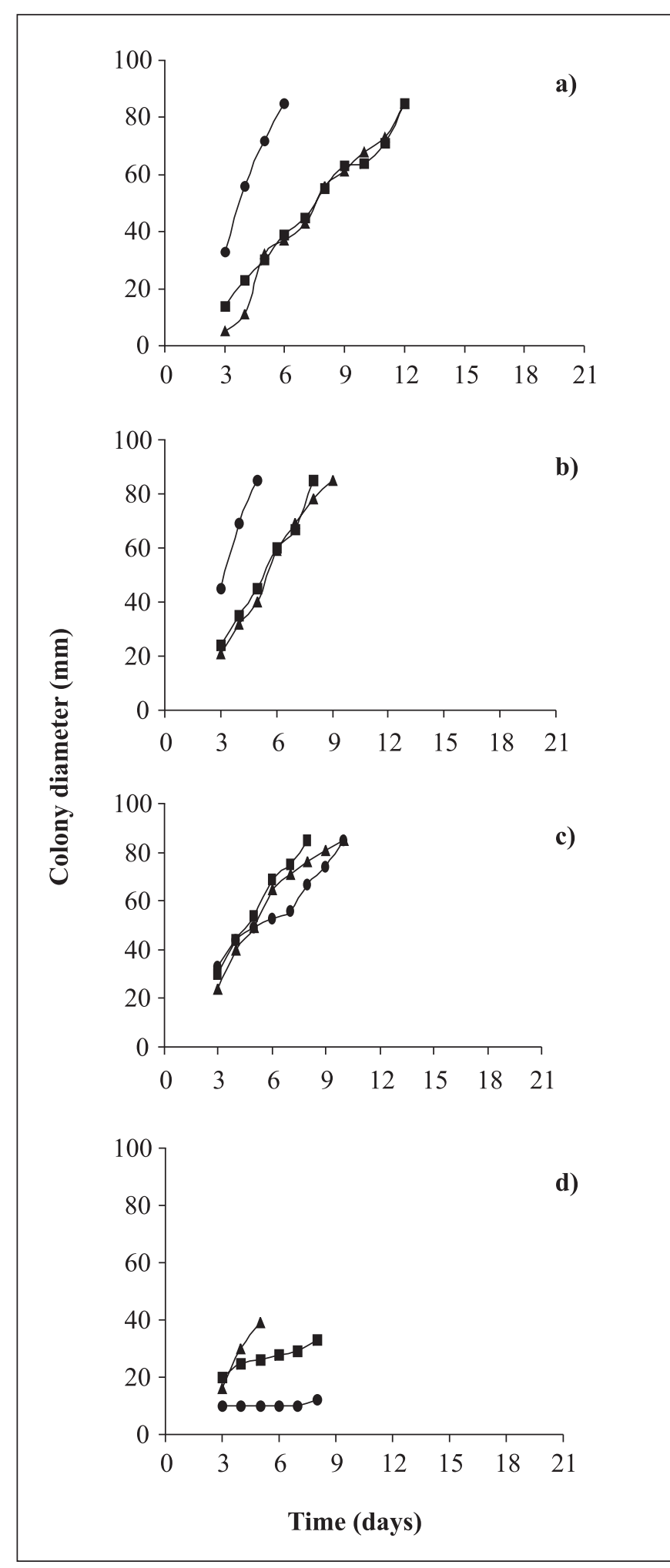

Figure 2. Growth of $A$. carbonarius on three different culture media ( CYA; DG18; $\triangle$ MY40G) at temperatures of a) $25^{\circ} \mathrm{C}$; b) $30^{\circ} \mathrm{C}$; c) $35^{\circ} \mathrm{C}$; d) $41^{\circ} \mathrm{C}$.

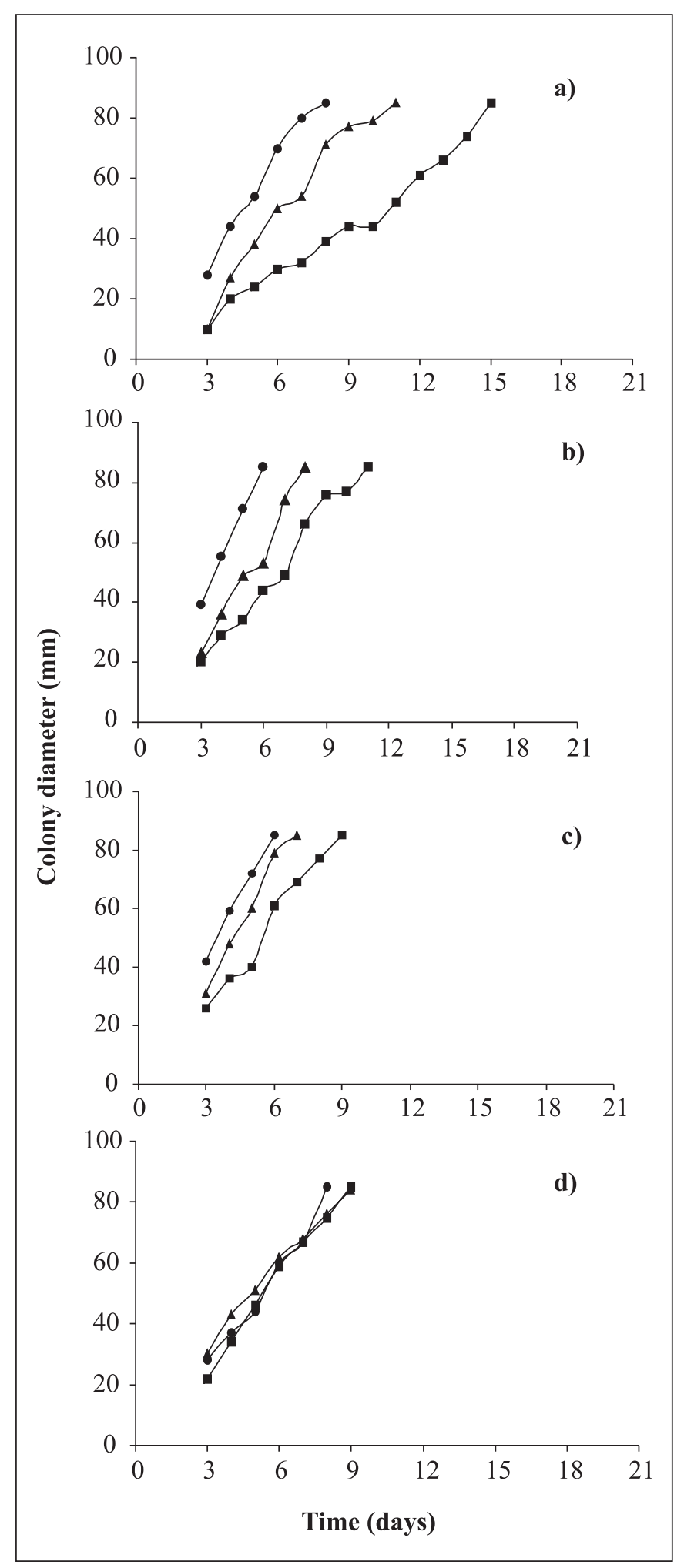

Figure 3. Growth of $A$. niger on three different culture media; ( CYA; DG18; $\triangle \mathrm{MY} 40 \mathrm{G}$ ) at the temperatures of a) $25^{\circ} \mathrm{C}$; b) $30^{\circ} \mathrm{C}$; c) $35^{\circ} \mathrm{C}$; d) $41^{\circ} \mathrm{C}$. 
faster at $35^{\circ} \mathrm{C}$ on all culture media. This shows that $A$. niger prefers to grow at temperatures higher than $30^{\circ} \mathrm{C}$. At $41^{\circ} \mathrm{C}$, this species spread over the whole plate $(85 \mathrm{~mm})$ on CYA, DG18 and MY50G after 8, 9 and 10 days, respectively (Fig. 3). At the temperature of $41^{\circ} \mathrm{C}$, A. carbonarius was significantly inhibited in all culture media. The range of temperatures between 25 to $41^{\circ} \mathrm{C}$ was not a limiting factor for growth of A. niger. A. carbonarius grew faster than $A$. ochraceus at temperatures above $30^{\circ} \mathrm{C}$, especially at $35^{\circ} \mathrm{C}$. Significant differences in $\mathrm{a}_{\mathrm{w}}$ and temperature were observed for the growth of all the species tested.

Statistical analyses showed significant differences between species $(\mathrm{P}<0.001)$ due to $\mathrm{a}_{\mathrm{w}}$, temperature, species, and two-and three-way interactions (Table 1).

Analysing the data for species as it is shown in Table 2 a similar tendency can be observed from the data of Table 1, in relation to the single effect. The differences appeared when the interactions of the effects of $a_{w} X$ temperature were compared. However, they were only significant for $A$. ochraceus. Another fact which should be emphasized is the interaction of time $\mathrm{X} \mathrm{a}_{\mathrm{w}}$, which was only statistically significant for A. niger (Table 2).

\section{DISCUSSION}

The temperature of $8^{\circ} \mathrm{C}$ was inhibitory for $A$. ochraceus, A. carbonarius and A. niger. Pitt and Hocking (19), have recorded minimum growth of $A$. niger and $A$. ochraceus at 6 and $8^{\circ} \mathrm{C}$, respectively, which differs from the data obtained in the present experiment. This may be due to the differences among the strains isolated from different origins around the world. A. carbonarius although similar to A. niger, has its own distinct growth character, especially at temperatures higher than $35^{\circ} \mathrm{C}$. While A. niger grew very well at $41^{\circ} \mathrm{C}$ on all media, $A$. carbonarius did so poorly. A. ochraceus did not grow at all at $41^{\circ} \mathrm{C}$ in all culture media. The media with reduced $\mathrm{a}_{\mathrm{w}}$ such as DG18 and MY40G, were not a limiting factor for these three species. On MY40G ( $a_{w}$ 0.897), the three species were able to grow at temperatures from 25 to $35^{\circ} \mathrm{C}$. A. carbonarius grew better at MY40G than CYA at $41^{\circ} \mathrm{C}$. These observations may suggest that the substrate may influence the thermotrophic behaviour of the fungi. MY40G has a higher sugar concentration than CYA. Although DG18 is not a suitable medium to study the kinetic of fungal growth, it was also included because it is commonly used to isolate fungi from food and it was important to evaluate the behaviour of these three species on this medium. Studies on culture media with different compositions and water activities at the laboratorial level are useful in order to follow the kinetic of fungal growth under different conditions.
Table 1. Analysis of co-variance of the effect of water activity of the culture media $\left(\mathrm{a}_{\mathrm{w}}\right)$, temperature $(\mathrm{T})$, time $(\mathrm{t})$ and species (S) and their interactions, on the colony diameter of Aspergillus ochraceus, Aspergillus niger and Aspergillus carbonarius.

\begin{tabular}{lcrc}
\hline Factor & df & \multicolumn{1}{c}{ MS } & \multicolumn{1}{c}{$\mathrm{F}$} \\
\hline $\mathrm{S}$ & 2 & 2763.90 & $285.01^{*}$ \\
$\mathrm{a}_{\mathrm{w}}$ & 2 & 1759.57 & $181.44^{*}$ \\
$\mathrm{~T}$ & 2 & 620.09 & $63.94^{*}$ \\
$\mathrm{t}$ & 2 & 6125.14 & $315.81^{*}$ \\
$\mathrm{~S} \mathrm{X} \mathrm{a} \mathrm{w}_{\mathrm{w}}$ & 4 & 710.49 & $73.27^{*}$ \\
$\mathrm{~S} \mathrm{X} \mathrm{T}$ & 4 & 320.57 & $33.06^{*}$ \\
$\mathrm{~S} \mathrm{X} \mathrm{t}$ & 4 & 72.72 & 7.50 \\
$\mathrm{a}_{\mathrm{w}}$ X T & 4 & 323.68 & $33.38^{*}$ \\
$\mathrm{a}_{\mathrm{w}}$ X t & 4 & 31.38 & 3.24 \\
$\mathrm{~T} \mathrm{X} \mathrm{t}$ & 4 & 13.01 & 1.34 \\
$\mathrm{~S} \mathrm{X} \mathrm{T} \mathrm{X} \mathrm{t}$ & 8 & 7.27 & 0.75 \\
$\mathrm{~S} \mathrm{X} \mathrm{a} \mathrm{a}_{\mathrm{w}} \mathrm{t}$ & 8 & 28.84 & 2.97 \\
$\mathrm{~S} \mathrm{X} \mathrm{a}$ & 8 & 80.38 & $8.29^{*}$ \\
$\mathrm{a}_{\mathrm{w}}$ X T X t & 8 & 12.05 & 1.24 \\
\hline
\end{tabular}

* Significant $\mathrm{P}<0.001$.

Table 2. Analysis of co-variance of the effect of water activity of the culture media $\left(\mathrm{a}_{\mathrm{w}}\right)$, temperature $(\mathrm{T})$, time $(\mathrm{t})$ on the colony diameter of Aspergillus ochraceus, Aspergillus niger and Aspergillus carbonarius on CYA, DG18 and MY40G.

\begin{tabular}{clrll}
\hline Species & Factor & df & \multicolumn{1}{c}{ MS } & \multicolumn{1}{c}{$\mathrm{F}$} \\
\hline A. ochraceus & $\mathrm{a}_{\mathrm{w}}$ & 2 & 900.60 & $53.41^{*}$ \\
& $\mathrm{~T}$ & 2 & 2167.31 & $128.52^{*}$ \\
& time & 10 & 2478.75 & $146.99^{*}$ \\
& $\mathrm{a}_{\mathrm{w}} \mathrm{X} \mathrm{T}$ & 4 & 796.53 & $47.24^{*}$ \\
& $\mathrm{a}_{\mathrm{w}} \mathrm{X}$ time & 20 & 20.62 & 1.22 \\
& $\mathrm{~T}$ X time & 20 & 61.78 & $3.66^{*}$ \\
A. niger & $\mathrm{a}_{\mathrm{w}}$ & 2 & 1438.48 & $1117.67^{*}$ \\
& $\mathrm{~T}$ & 2 & 719.37 & $558.94^{*}$ \\
& time & 2 & 1272.93 & $989.04^{*}$ \\
& $\mathrm{a}_{\mathrm{w}} \mathrm{X} \mathrm{T}$ & 4 & 13.81 & $10.73(\mathrm{p}=0.0027)$ \\
& $\mathrm{a}_{\mathrm{w}} \mathrm{X}$ time & 4 & 53.37 & $41.47^{*}$ \\
& $\mathrm{~T} \mathrm{X}$ time & 4 & 2.09 & 1.63 \\
A. carbonarius & $\mathrm{a}_{\mathrm{w}}$ & 2 & 1681.81 & $61.20^{*}$ \\
& $\mathrm{~T}$ & 2 & 435.59 & $15.85(\mathrm{p}=0.0016)$ \\
& time & 2 & 1436.26 & $52.26^{*}$ \\
& $\mathrm{a}_{\mathrm{w}} \mathrm{X} \mathrm{T}$ & 4 & 346.48 & $12.61(\mathrm{p}=0.0016)$ \\
& $\mathrm{a}_{\mathrm{w}} \mathrm{X}$ time & 4 & 30.15 & 1.10 \\
& $\mathrm{~T} \mathrm{X}$ time & 4 & 11.26 & 0.41 \\
\hline
\end{tabular}

*Significant $\mathrm{P}<0.001$ 


\section{ACNOWLEDGEMENTS}

The authors wish to thank Consórcio Brasileiro de Pesquisa e Desenvolvimento do Café for the financial support, to Fundação de Amparo à Pesquisa do Estado de São Paulo (FAPESP) for funding the $\mathrm{PhD}$ program for H.P. and Mr. S. Shaw for reviewing the manuscript.

\section{RESUMO}

\section{Crescimento de Aspergillus ochraceus, A. carbonarius e A. niger em meios de cultura com diferentes atividades de água e temperaturas}

Esporos de A. ochraceus, A. carbonarius e A. niger foram inoculados em três meios de cultura: Agar extrato de levedura Czapeck (CYA), Agar Glicerol 18\% com dicloran (DG18), Agar Extrato de levedura e malte com $40 \%$ de glicose (MY40G). As placas foram incubadas em 5 temperaturas diferentes: 8, 25, 30, 35 e $41^{\circ} \mathrm{C}$. O crescimento dos fungos foi avaliado medindo o diâmetro da colônia a cada $24 \mathrm{~h}$. O objetivo deste trabalho foi determinar a influência de três meios de cultura com atividade de água diferente tempo de incubação e temperaturas, sobre o crescimento de A. ochraceus, A. carbonarius and A. niger. Nenhuma das espécies cresceu à $8^{\circ} \mathrm{C}$ em nenhum dos meios de cultura. Para A. carbonarius, $30^{\circ} \mathrm{C}$ foi a melhor temperatura para o seu crescimento enquanto para $A$. niger temperaturas acima de $30^{\circ} \mathrm{C}$ foram melhores em todos os meios de cultura. $A$. ochraceus apresentou bom crescimento a 25 e $30^{\circ} \mathrm{C}$ em todos os meios de cultura, enquanto seu crescimento à $35^{\circ} \mathrm{C}$ foi mais lento, especialmente no meio CYA. A $41^{\circ} \mathrm{C}, A$. ochraceus não cresceu em nenhum dos meios de cultura estudados e $A$. carbonarius foi significantemente inibido. A. niger cresceu à temperatura de $41^{\circ} \mathrm{C}$ e apresentou-se como o fungo mais xerofílico, comparado com A. carbonarius e A. ochraceus.

Palavras-chave: Aspergillus ochraceus, Aspergillus carbonarius, Aspergillus niger, medida de crescimento, atividade de água, temperatura

\section{REFERENCES}

1. Abarca, M.L.; Bragulat, G.; Castellá, G.; Cabanes, F.J. Ochratoxin A production by strains of Aspergillus niger var. niger. Appl. Environ. Microbiol., 60, 2650-2652, 1994.

2. Bucheli, P.; Taniwaki, M.H. Research on the origin, and on the impact of post-harvest handling and manufacturing on the presence of ochratoxin A in coffee. Food Addit. Contamin., 19, 655-665, 2002.

3. Christensen, C.H. Invasion of stored wheat by Aspergillus ochraceus. Cereal Chem. 39, 100-106, 1962.

4. Frank, J.M. On the activity of fungi in coffee in relation to ochratoxin A production. 19 $9^{\text {th }}$ ASIC Coffee Conference, Trieste, Italy, 2001. CD room.

5. Guldborg, M. Ochratoxin A in Danish beer. Brygmesteren., 54, 1617, 1997.
6. Heenan, C.N.; Shaw, K.J.; Pitt, J.I. Ochratoxin A production by Aspergillus carbonarius and A. niger isolates and detecting using coconut cream agar. J. Food Mycol., 1, 67-72, 1998.

7. Hocking, A.D.; Pitt, J.I. Dichloran-glycerol medium for enumeration of xerophilic fungi from low moisture foods. Appl. Environ. Microbiol., 39, 488-492, 1980.

8. JECFA (Joint FAO/WHO Expert Commitee on Food Additives) Safety evaluation of certain mycotoxins in foods. WHO Food Additives Series 47, World Health Organization, Geneva, 2001.

9. Jorgensen, K.; Bilde, B. Occurrence and estimated dietary intakes of ochratoxin A in European countries - results from SCOOP Project. Food Addit. Contamin. Supplem., 13S, 15-16, 1996.

10. Klich, M.A.; Pitt, J.I. A Laboratory Guide to Common Aspergillus species and their Teleomorphs. CSIRO Division of Food Science and Technology, Sydney, Australia, 1988.

11. Levi, P.C.; Trenk, H.L.; Mohr, H.K. Study of the occurrence of ochratoxin A in green coffee beans. J. Assoc. Offic. Analyt. Chem., 57, 866-870, 1974.

12. MacDonald, S.; Wilson, P.; Barnes, K.; Damant, A.; Massey, R.; Mortby, E.; Shepherd, M.J. Ochratoxin A in dried vine fruit: method development and survey. Food Addit. Contamin., 16, 253-260, 1999.

13. MAFF (Ministry of Agriculture, Fisheries and Food). Survey of aflatoxins and ochratoxin A in cereals and retail products. MAFF Food Surveillance Information Sheet 130, London, 1997.

14. Matissek, R.; Raters, M. Ochratoxin A in cocoa and human health aspects. $13^{\text {th }}$ International Cocoa Research Conference, Kota Kinabalu, Malaysia, 9-14 October, 2000.

15. Otteneder, H.; Majerus, P. Occurrence of ochratoxin A (OTA) in wines: influence of the type of wine and its geographical origin. Food Addit. Contamin., 17, 793-798, 2000.

16. Paster, N.; Chet, I. Effects of environmental factors on growth and sclerotium formation in Aspergillus ochraceus. Can. J. Bot., 58, 1844-1850, 1980.

17. Pitt, J.I. The Genus Penicillium and its Teleomorphic States Eupenicillium and Talaromyces. London: Academic Press, 1979.

18. Pitt, J.I. Penicillium viridicatum, Penicillium verrucosum and production of ochratoxin A. Appl. Environ. Microbiol., 53, 266-269, 1987.

19. Pitt, J.I.; Hocking, A.D. Fungi and Food Spoilage Blackie, London, 1997.

20. Pohland, A.E.; Nesheim, S.; Friedman, L. Ochratoxin A: a review. Pure Appl. Chem., 64, 1029-1046, 1992.

21. Ramos, A.J.; Labernia, N.; Marín, S.; Sanchis, V.; Magan, N. Effect of water activity and temperature on growth and ochratoxin production by three of Aspergillus ochraceus on a barley extract medium and on barley grains. Intern. J. Food Microbiool., 44, 133-140, 1998.

22. Stegen, G.V.D.; Jorissen, U.; Pittet, A.; Saccon, M.; Steiner, W.; Vincenzi, M.; WIinkler, M.; Zapp, J.; Schaltter, C. Screening of European coffee final products for occurrence of ochratoxin A (OTA). Food Addit. Contamin., 14, 211-216, 1997.

23. Taniwaki, M.H.; Pitt, J.I.; Teixeira, A.A.; Iamanaka, B.T. The source of ochratoxin A in Brazilian coffee and its formation in relation to processing methods. Intern. J. Food Microbiol., 82, 173-179, 2003.

24. Téren, J.; Varga, J.; Hamari, Z.; Rinyu, E.; Kevei, É. Immunochemical detection of ochratoxin A in black Aspergillus strains. Mycopathol., 134, 171-176, 1996.

25. WHO Report of the $56^{\text {th }}$ Meeting of the Joint FAO/WHO Expert Committee on Food Additives, Geneva, Switzerland, 6-15 February, 2001.

26. Zimmerli, B.; Dick, R. Determination of ochratoxin A at the ppt level in human blood, serum, milk and some foodstuffs by highperformance liquid chromatography with enhanced fluorescence detection and immunoaffinity column cleanup methodology and Swiss data. J. Chromat., 666, 85-99, 1995.

27. Zimmerli, B.; Dick, ROchratoxin A in table wine and grape-juice: occurrence and risk assessment. Food Addit. Contamin., 13, 655$668,1996$. 